удК $332.122(470+571)$

О. А. Чепинога

Байкальский государственный университет, г. Иркутск, Российская Федераџия

М. В. Солодков

Байкальский государственный университет, 2. Иркутск, Российская Федерация

А. Э. Семенова

Байкальский государственный университет, г. Иркутск, Российская Федерация

\title{
ПРОБЛЕМЫ ФУНКЦИОНИРОВАНИЯ И ПЕРСПЕКТИВЫ РАЗВИТИЯ ОСОБЫХ ЭКОНОМИЧЕСКИХ ЗОН В РОССИИ
}

\begin{abstract}
АНнотАЦИЯ. В настоящее время свободные экономические зоны (СЭЗ) активно используются в мире как инструмент региональной политики. Опыт создания СЭЗ в России в 90-е годы нельзя назвать успешным. С 2005 г. в связи с принятием Федерального закона «Об особых экономических зонах в Российской Федерации» в нашей стране вновь активно применятся этот инструмент, продолжает формироваться нормативная база, нарабатывается опыт. В России созданы ОЭЗ промышленно-производственного, технико-внедренческого, туристско-рекреационного и портового типов. Однако и сегодня эффективность функционирования СЭЗ в России вызывает сомнения, в связи с чем требуется переосмысление теоретических наработок, а также зарубежного опыта в указанной сфере. В статье анализируется функционирование СЭЗ в России, выявлены проблемы, препятствующие их развитию, определены направления их решения.

кЛЮчЕВЫЕ слОВА. Свободные экономические зоны (СЭЗ); особые экономические зоны (ОЭЗ); привлечение инвестиций; полюса роста; точки роста.

ИНФОРМАЦИЯ О СТАТЬЕ. Дата поступления 26 июля 2017 г.; дата принятия к печати 11 октября 2017 г.; дата онлайн-размещения 25 октября 2017 г.
\end{abstract}

O. A. Chepinoga Baikal State University, Irkutsk, Russian Federation

M. V. Solodkov Baikal State University, Irkutsk, Russian Federation

A. E. Semenova Baikal State University, Irkutsk, Russian Federation

\section{PROBLEMS OF FUNCTIONING AND DEVELOPMENT PROSPECTS FOR SPECIAL ECONOMIC ZONES IN RUSSIA}

ABSTRACT. At the present time, Free Economic Zones (FEZ) are actively used in the world as an instrument of regional policy. The experience of FEZ creation in Russia in the 90s can not be called successful. Since 2005, in relation to the adoption of the Federal Law 'On Special Economic Zones in the Russian Federation' this instrument has been actively used again in our country, the normative base continues to develop, and the experience is being gained. The SEZ for industrial and production, technological and innovative, tourist-recreational and port types have been created in Russia. However, the effectiveness of the FEZ functioning causes doubts nowadays, therefore a rethinking of the theoretical developments is required, as well as the foreign experience in the area specified. The article analyses the FEZ functioning in Russia, identifies the problems impedient for their development, determines the directions for their solutions.

\section{Baikal Research Journal}


KEYWORDS. Free Economic Zones (FEZ); Special Economic Zones (SEZ); investment promotion; growth poles; growth points.

ARTICLE INFO. Received July 26, 2017; accepted October 11, 2017; available online October 25, 2017.

Для решения проблем социально-экономического развития, таких как необходимость диверсификации экономики, развитие отдельных территорий, привлечение инвестиций, создание рабочих мест, развитие перспективных отраслей экономики, стимулирование научно-технического прогресса государства используют множество инструментов. Свободные экономические зоны являются одним из таких инструментов, причем достаточно эффективным. В мире функционирует несколько тысяч свободных экономических зон с различным набором льгот и преференций.

Определение понятия «свободная экономическая зона» приведено в Международной конвенции по упрощению и гармонизации таможенных процедур (Киото, 1973 г.): «часть территории страны, в пределах которой любые прибывшие на нее товары обычно рассматриваются, в том, что касается импортных пошлин и налогов, как товары, находящиеся за пределами таможенной территории (принцип «таможенной экстерриториальности»), поэтому они не подвергаются обычному таможенному контролю и налогообложению» ${ }^{\circ}$

В российском законодательстве используется понятие «особая экономическая зона». В соответствии со ст. 2 Федерального закона от 22.05.2005 г. № 116-ФЗ «Об особых экономических зонах в Российской Федерации» особая экономическая зона (ОЭЗ) - это определяемая Правительством РФ часть территории, на которой действует особый режим осуществления предпринимательской деятельности. За рубежом используются аналогичные понятия ОЭЗ. Отличаются они лишь тем, что в соответствии с законодательством большинства стран такие зоны называются свободными (или специальными), а не особыми.

Вопросам создания и функционирования свободных (особых) экономических зон уделяли внимание Бутов В. И., Игнатов В. Г. [1], Павлов П. В. [2, 3], Приходько С. В., Воловик Н. П. [4], Данько Т. П., Окрут З. М. [5], Федин П. А. [6], Шмонов Н. Н. [7] и другие исследователи.

Выделяют следующие признаки СЭЗ [8, с. 3]:

1. СЭЗ является обособленной территорией (частью национального пространства).

2. На территории СЭЗ действует особый режим предпринимательской деятельности.

3. Для регулирования деятельности СЭЗ создается специальный орган управления.

4. Цели создания зон различны в зависимости от уровня социально-экономического развития государства.

5. Функционирование СЭЗ направлено на содействие отечественным и иностранным предпринимателям.

Организационно-функциональная структура свободных экономических зон достаточно многообразна. В теоретической литературе выделяют до 30 различных видов свободных экономических зон. Так С. В. Приходько и Н. П. Воловик выделяют пять основных видов ОЭЗ (табл. 1).

1 Об упрощении и гармонизации таможенных процедур : междунар. конвенция от 18.05.1973 // Таможня.ру : информ.-аналит. портал. URL: http://www.tamognia.ru/doc_base/ document.php?id=1571053\# odislth.

\section{Baikal Research Journal}

электронный научный журнал Байкальского государственного университета 
Таблица 1

Классификация ОЭЗ в соответствии с хозяйственной специализацией

\begin{tabular}{|c|c|c|c|c|}
\hline Торговые & $\begin{array}{c}\text { Промышленно- } \\
\text { производственные }\end{array}$ & $\begin{array}{c}\text { Технико- } \\
\text { внедренческие }\end{array}$ & Сервисные & Комплексные \\
\hline $\begin{array}{l}\text { 1. Свободные тамо- } \\
\text { женные } \\
2 . \text { Бондовые } \\
\text { склады } \\
\text { 3. Свободные } \\
\text { порты } \\
\text { 4. Торгово-произ- } \\
\text { водственные }\end{array}$ & $\begin{array}{l}\text { 1. Импортозамеща- } \\
\text { ющие } \\
\text { 2. Экспортно-произ- } \\
\text { водственные (ЭПЗ) } \\
\text { 3. Промышленные } \\
\text { парки } \\
\text { 4. Научно-промыш- } \\
\text { ленные парки } \\
\text { 5. Экспортно-импор- } \\
\text { тозамещающие }\end{array}$ & $\begin{array}{l}\text { 1. Технополисы } \\
\text { 2. Технопарки } \\
\text { 3. Инновацион- } \\
\text { ные центры }\end{array}$ & $\begin{array}{l}\text { 1. Оффшорные } \\
\text { 2. Банковских } \\
\text { и страховых } \\
\text { услуг } \\
\text { 3. Туристиче- } \\
\text { ских услуг }\end{array}$ & $\begin{array}{l}\text { 1. Зоны свобод- } \\
\text { ного предприни- } \\
\text { мательства } \\
\text { 2. Специальные } \\
\text { экономические } \\
\text { зоны } \\
\text { 3. Территории } \\
\text { особого режима } \\
\text { 4. Особые эконо- } \\
\text { мические зоны }\end{array}$ \\
\hline
\end{tabular}

Источник: [4].

Шмонов Н. Н. классифицирует ОЭЗ по выполняемым функциям (зоны свободной торговли, промышленно-производственные, технико-внедренческие, туристско-рекреационные, сервисные, комплексные); степени интеграции в экономику (интегрированные в национальную экономику, анклавные (экспортоориентированные)) и системам предоставляемых льгот (налоговые, таможенные, финансовые, административные) [7].

Павлов П. В. приводит схожую классификацию, однако выделяет международные СЭЗ в отдельную группу [2, с. 353]. Сюда входят различные формы международных интеграционных объединений - зона свободной торговли (ЕАСТ, НАФТА), таможенный союз (Арабский общий рынок, ЕАЭС), общий рынок (МЕРКОСУР, Андский общий рынок), экономический союз (ЕС).

В России впервые свободные экономические зоны начали образовываться в конце 80-х гг. Сегодня можно говорить о втором этапе их функционирования, он начался в 2005 г. с принятием соответствующего федерального закона. В России предусмотрено создание четырех типов ОЭЗ в зависимости от видов деятельности, которыми могут заниматься инвесторы: промышленно-производственного типа (ППТ); технико-внедренческого типа (ТВТ); туристско-рекреационного типа (ТРТ); портового типа (ПТ).

При создании ОЭЗ, высший исполнительный орган государственной власти субъекта РФ совместно с исполнительно-распорядительным органом муниципального образования подают в уполномоченный Правительством РФ федеральный орган исполнительной власти заявку на создание ОЭЗ, которая должна содержать сведения о типе ОЭЗ и обоснование целесообразности и эффективности создания ОЭЗ для решения задач федерального, регионального, местного значения ${ }^{2}$, должна соответствовать критериям создания ОЭЗ, утвержденным постановлением Правительства РФ от 26.04.2012 № 398 «Об утверждении критериев создания особой экономической зоны».

Анализ функционирования особых экономических зон (ОЭЗ) проводится ежегодно Министерством экономического развития Российской Федерации согласно установленным правилам ${ }^{3}$ по 16 абсолютным и относительным количественным по-

2 Об утверждении Порядка оформления и подачи заявки на создание особой экономической зоны, в том числе перечня документов, прилагающихся к заявке [Электронный ресурс] : приказ Минэкономразвития России от 19.07.2012 № 439 : (ред. 22.12.2014) : (Зарегистрировано в Минюсте России 01.08.2012 № 25068) // СПС «Консультант-Плюс».

${ }^{3} \mathrm{O}$ порядке оценки эффективности функционирования особых экономических зон [Электронный ресурс] : постановление Правительства РФ от 07.07.2016 № 643 // СПС «Консультант-Плюс».

\section{Baikal Research Journal}

электронный научный журнал Байкальского государственного университета 
казателям (количество резидентов, количество заявленных и осуществленных инвестиций, количество созданных рабочих мест и т.д.) и 4 расчетным показателям:

1) показатель эффективности деятельности резидентов ОЭЗ $\left(E_{p e s}\right)$;

2) показатель, отражающий рентабельность вложения средств бюджетов всех уровней РФ в создание объектов инфраструктуры ОЭЗ $\left(R_{\phi \sigma}\right)$;

$3)$ показатель эффективности органов управления ОЭЗ $\left(E_{\text {oy }}\right)$;

4) сводный показатель эффективности $E_{о э з ~}=0,65 \cdot R_{\phi \sigma}+0,2 \cdot E_{p e s}+0,15 \cdot E_{\text {oy. }}$.

Оценка осуществляется по каждой особой экономической зоне, а также по всем четырем типам зон, за каждый отчетный период и за период с начала функционирования зон; в конце анализа результаты обобщаются в целом по всем зонам, формируется рейтинг эффективности функционирования российских ОЭЗ

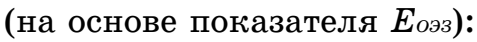

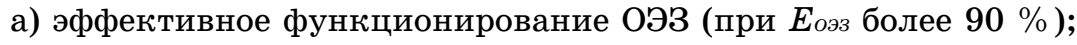

б) достаточно эффективное функционирование ОЭЗ (Eоэз от 50 до $90 \%)$;

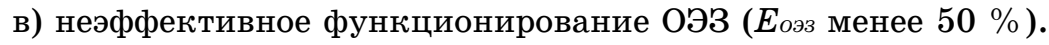

В последнем отчете о результатах функционирования ОЭЗ представлен следующий рейтинг эффективности ОЭЗ в России (табл. 2):

Таблица 2

Сравнительная рейтинговая оценка эффективности функиионирования ОЭЗ по типам ОЭЗ за 2015 г. и за период с начала функщионирования ОЭЗ, \%

\begin{tabular}{|c|c|}
\hline \multicolumn{2}{|c|}{ ОЭЗ ППТ } \\
\hline За 2015 год & $\begin{array}{c}\text { Накопленным итогом за период с начала } \\
\text { функционирования ОЭЗ }\end{array}$ \\
\hline $\begin{array}{l}\text { ОЭЗ ППТ в Республике Татарстан - } 100 \\
\text { ОЭЗ ППТ в Самарской области - } 81 \\
\text { ОЭЗ ППТ в Липецкой области }-75 \\
\text { ОЭЗ ППТ в Калужской области }-53 \\
\text { ОЭЗ ППТ в Свердловской области }-30\end{array}$ & $\begin{array}{l}\text { ОЭЗ ППТ в Республике Татарстан - } 100 \\
\text { ОЭЗ ППТ в Липецкой области - 100 } \\
\text { ОЭЗ ППТ в Свердловской области - } 79 \\
\text { ОЭЗ ППТ в Калужской области }-72 \\
\text { ОЭЗ ППТ в Самарской области }-63\end{array}$ \\
\hline \multicolumn{2}{|c|}{ OЭЗ ТВТ } \\
\hline За 2015 год & $\begin{array}{c}\text { Накопленным итогом за период с начала } \\
\text { функционирования ОЭЗ }\end{array}$ \\
\hline $\begin{array}{l}\text { ОЭЗ ТВТ в Московской области }-100 \\
\text { ОЭЗ ТВТ в г. Санкт-Петербурге }-96 \\
\text { ОЭЗ ТВТ в г. Томске - } 93 \\
\text { ОЭЗ ТВТ в г. Москве - } 73 \\
\text { ОЭЗ ТВТ в Республике Татарстан }-15\end{array}$ & $\begin{array}{l}\text { ОЭЗ ТВТ в г. Москве - } 100 \\
\text { ОЭЗ ТВТ в г. Санкт-Петербурге }-96 \\
\text { ОЭЗ в г. Томске }-86 \\
\text { ОЭЗ ТВТ в Московской области }-71 \\
\text { ОЭЗ ТВТ в Республике Татарстан }-40\end{array}$ \\
\hline \multicolumn{2}{|r|}{ ОЭЗ ТРТ } \\
\hline За 2015 год & $\begin{array}{c}\text { Накопленным итогом за период с начала } \\
\text { функционирования ОЭЗ }\end{array}$ \\
\hline $\begin{array}{l}\text { ОЭЗ ТРТ в Алтайском крае - } 77 \\
\text { ОЭЗ ТРТ в Республике Бурятия - } 65 \\
\text { ОЭЗ ТРТ в Карачаево-Черкесской } \\
\text { Республике - } 43\end{array}$ & $\begin{array}{l}\text { ОЭЗ ТРТ в Республике Бурятия - } 55 \\
\text { ОЭЗ ТРТ в Республике Чечня - } 40 \\
\text { ОЭЗ ТРТ в Карачаево-Черкесской } \\
\text { Республике - } 39 \\
\text { ОЭЗ ТРТ в Алтайском крае }-36\end{array}$ \\
\hline \multicolumn{2}{|r|}{ ОЭЗ ПТ } \\
\hline За 2015 год & $\begin{array}{c}\text { Накопленным итогом за период с начала } \\
\text { функционирования ОЭЗ }\end{array}$ \\
\hline ОЭЗ ПТ в Ульяновской области - 27 & ОЭЗ ПТ в Ульяновской области - 33 \\
\hline
\end{tabular}

Источник: Отчет о результатах функционирования особых экономических зон за 2015 год и за период с начала функционирования особых экономических зон [Электронный ресурс] // Сайт Министерства экономического развития Российской Федерации. - Режим доступа: http://economy.gov. $\mathrm{ru} / \mathrm{minec} /$ about/structure/depOsobEcZone/2160930.

\section{Baikal Research Journal}


Наиболее эффективными зонами признаются ОЭЗ промышленно-производственного типа (83\%) и ОЭЗ технико-внедренческого типа $(79 \%)$, наименьшее значение присвоено ОЭЗ туристско-рекреационного типа $(43 \%)$ и портовым ОЭЗ (33 \%). Наиболее эффективными ОЭЗ ППТ являются ОЭЗ «Алабуга» в Республике Татарстан и ОЭЗ «Липецк» в Липецкой области, наиболее эффективные ОЭЗ ТВТ - ОЭЗ «Дубна» в Московской области, ОЭЗ «Санкт-Петербург». Низкая активность ОЭЗ ТРТ и ПТ, прежде всего, обусловлена незавершенностью объектов инфраструктуры этих типов зон.

Согласно данным Министерства экономического развития РФ, по состоянию на декабрь 2015 г. на территориях ОЭЗ было зарегистрировано 439 резидентов (108\% от плановых значений), причем 83 из них - в 2015 г. (128\% от плановых значений), за весь период существования ОЭЗ статус резидента утратили 129 компаний, из них $17-$ за $2015 г^{4}$ Согласно же данным управляющей компании АО «ОЭЗ» ${ }^{5}$, к концу 2015 г. в ОЭЗ было привлечено 472 инвестора, в том числе в течение 2015 г. было привлечено 111 инвесторов (рис. 1). По состоянию на 31 декабря 2015 г. в ОЭЗ было привлечено 79 инвесторов с участием иностранного капитала из 29 стран мира (Южная Корея, Италия, США, Германия, Нидерланды, Швейцария, Казахстан, Китай, Турция и т.д.) $)^{6}$, из них за 2015 г. привлечено 16 компаний с участием иностранного капитала.

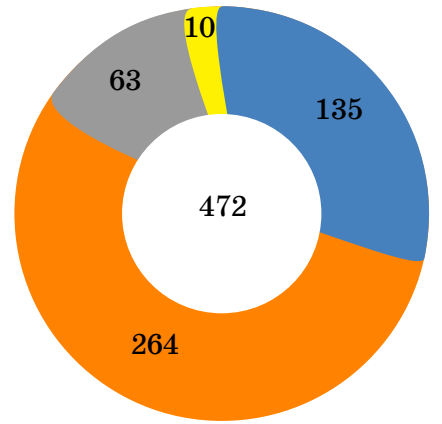

Количество инвесторов по состоянию на 31.12 .2015 г.

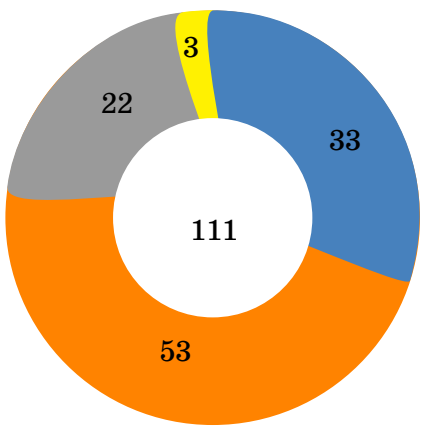

Количество инвесторов, привлеченных в 2015 г.

$$
\text { ОЭЗ ППт } \square \text { ОЭЗ ТВТ } \square \text { ОЭЗ ТРТ }
$$

Рис. 1. Общее количество инвесторов в ОЭЗ Составлено по данным годового отчета $A O$ «ОЭЗ» за 2015 г. (URL: http://www.russez.ru)

Согласно данным Министерства экономического развития РФ по состоянию на 31 декабря 2015 г. резидентами ОЭЗ осуществлено инвестиций, в том числе капитальных вложений, на сумму более 181 млрд р. (97 \% от плановых значений) в том числе за год оценки эффективности - 31481 млн р. (79\% от плановых значений). Резидентами создано 18520 рабочих мест (103\% от плановых значений) (рис. 2).

\footnotetext{
${ }^{4}$ Отчет о результатах функционирования особых экономических зон за 2015 год и за период с начала функционирования особых экономических зон // Министерство экономического развития PФ. URL: http://economy.gov.ru/minec/about/structure/depOsobEcZone/2160930.

${ }^{5}$ Годовой отчет АО «ОЭЗ» за 2015 г. // РосОЭЗ. Особые Экономические Зоны. URL: http://www. russez.ru/.

${ }^{6}$ Особые экономические зоны // Министерство экономического развития PФ. URL: http://economy. gov.ru/minec/activity/sections/sez/main/.
}

\section{Baikal Research Journal}




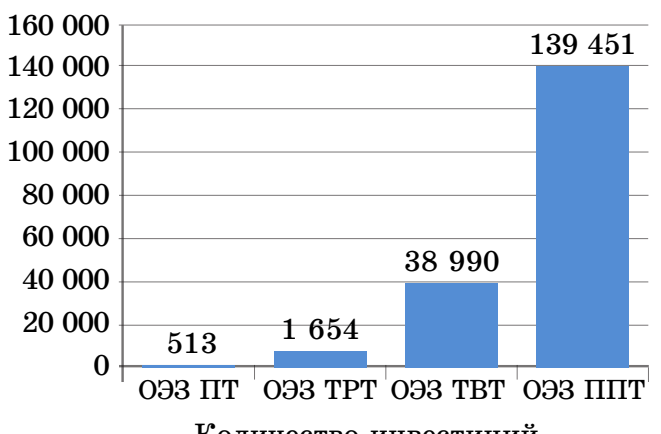

Количество инвестиций

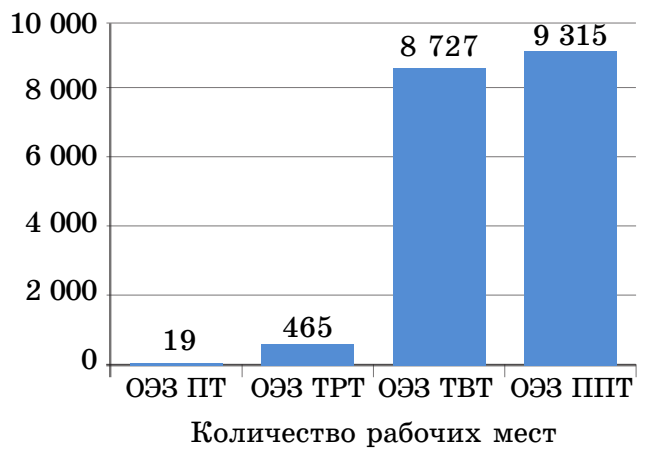

Рис. 2. Осуществленные резидентали ОЭЗ инвестищии (млн р.)

и количество созданных рабочих мест (ед.) по состоянию на 31.12 .2015 г.

Составлено по данным отчета о результатах функиионирования особых экономических зон за 2015 год и за период с начала функщионирования особых экономических зон (URL: http://economy.gov.ru/minec/about/structure/depOsobEcZone/

2160930 ); Годового отчета $A O$ «ОЭЗ» за 2015 г. (URL: http://www.russez.ru)

Объем выручки от продажи товаров, выполнения работ, оказания услуг за 2015 г. составил 64654 млн р. (114\% от плановых значений), нарастающим итогом за период с начала функционирования ОЭЗ - 249807 млн р. (107\% от плановых значений) (рис. 3).

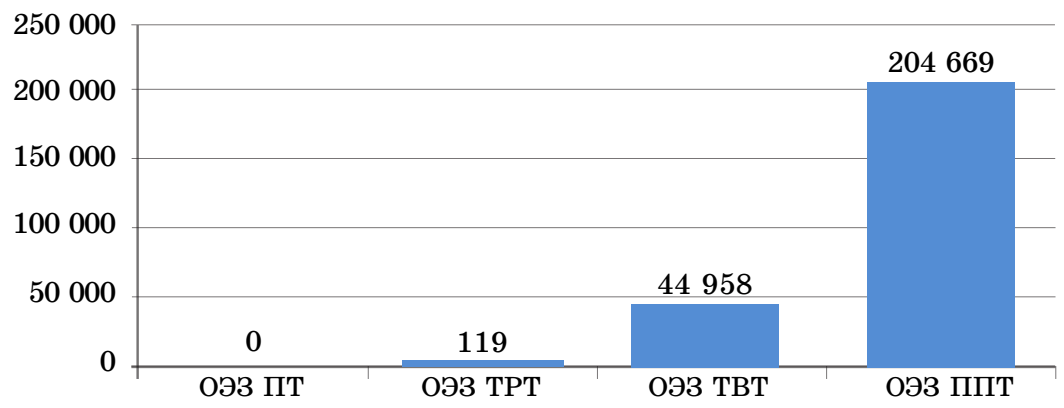

Рис. 3. Сумла доходов резидентов ОЭЗ на 31.12 .2015 г., млн р.

Составлено по данным отчета о результатах функиионирования особых экономических зон за 2015 год и за период с начала функционирования особых эконолических зон (URL: http://economy.gov.ru/minec/about/structure/depOsobEcZone/

2160930 ); Годовой отчет $A O$ «ОЭЗ» за 2015 2. (URL: http://www.russez.ru)

Объем налогов, уплаченных резидентами ОЭЗ в бюджеты всех уровней бюджетной системы РФ за период с начала функционирования ОЭЗ (по данным Минэкономразвития) составил 18222 млн р. (84\% от плановых значений), в том числе за 2015 г. - 5621 млн р. (106\% от плановых значений). Согласно же данным управляющей компании $\mathrm{AO}$ «ОЭЗ», общий накопленный объем налоговых отчислений резидентов ОЭЗ по итогам 2015 г. составил более 21 млрд р. (рис. 4). Объем таможенных платежей, уплаченных резидентами ОЭЗ за год оценки эффективности, составил 4130 млн р. ${ }^{7}$

${ }^{7}$ Отчет о результатах функционирования особых экономических зон за 2015 год и за период с начала функционирования особых экономических зон // Министерство экономического развития PФ. URL: http://economy.gov.ru/minec/about/structure/depOsobEcZone/2160930.

\section{Baikal Research Journal}




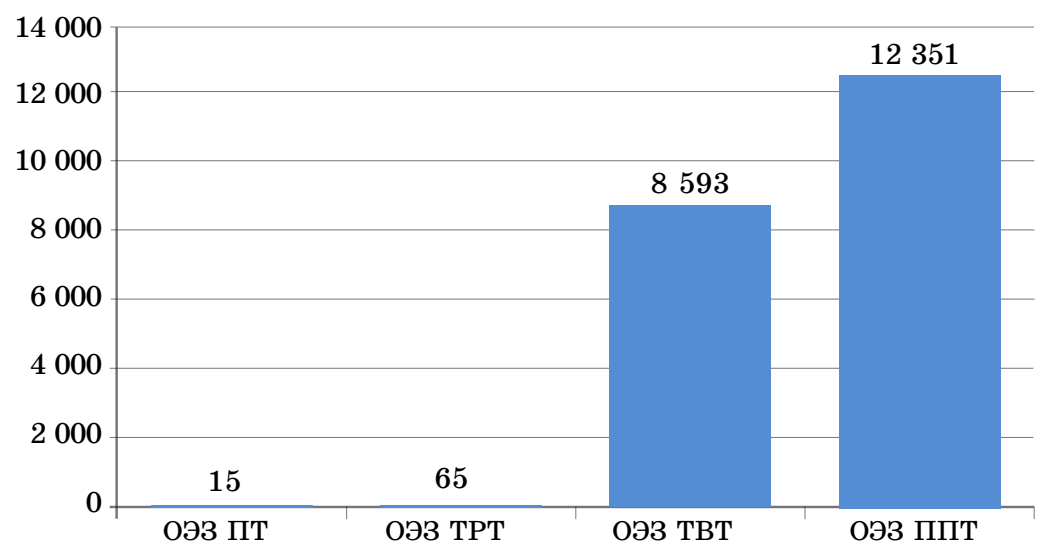

Рис. 4. Налоговые отчисления резидентов ОЭЗ в бюджеты всех уровней бюджетной системь РФ на 31.12.2015 г., ллн р.

Составлено по данным годового отчета $A O$ «ОЭЗ» за 2015 г. (URL: http://www.russez.ru)

Объем используемых налоговых льгот в части, зачисляемой в федеральный бюджет, полученных резидентами ОЭЗ за 2015 г. составил 202 млн р.; объем таможенных льгот, предоставленных резидентам ОЭЗ за 2015 г., составил 3871 млн р. По данным Минэкономразвития, объем средств федерального бюджета, направленных на финансирование объектов инфраструктуры ОЭЗ за год оценки эффективности ОЭЗ составил 20854 млн р. (55\% от плановых значений) ${ }^{8}$.

По тем же данным Минэкономразвития, за год оценки эффективности на территориях ОЭЗ построены и введены в эксплуатацию 46 объектов инженерной инфраструктуры (46 \% от плана); накопленным итогом за период с начала функционирования ОЭЗ - 464 объекта (94 \% от плановых значений).

Стоит отметить, что Правила оценки эффективности функционирования ОЭЗ были введены лишь в 2013 г. постановлением Правительства РФ «Об утверждении Правил оценки эффективности функционирования особых экономических зон» № 491 от 10.06.2013 г., и уже в 2015 г. утратили силу в связи с принятием постановления Правительства РФ от 07.07.2016 г. № 643 «О Порядке оценки эффективности функционирования особых экономических зон». Причем оценка проводится ежегодно уже после завершения отчетного периода деятельности ОЭЗ, и приведенные в Правилах показатели рассчитываются на основе установленных в Соглашении о передаче полномочий по управлению зоной плановых значений. Форма этого соглашения впервые была введена приказом Минэкономразвития РФ № 907 от 03.12.2015 г. «Об утверждении примерной формы соглашения о передаче полномочий по управлению особой экономической зоной органу исполнительной власти субъекта Российской Федерации» (данный приказ отменен приказом Министерства экономического развития РФ от 04.08.2016 г. № 502 «Об утверждении примерной формы соглашения о передаче полномочий по управлению особой экономической зоной органу исполнительной власти субъекта Российской Федерации», который на данный момент еще не вступил в силу). Таким образом, система оценки эффективности ОЭЗ в России находится в процессе формирования, его завершение важно для развития и совершенствования ОЭЗ.

${ }^{8}$ Отчет о результатах функционирования особых экономических зон за 2015 год и за период с начала функционирования особых экономических зон // Министерство экономического развития PФ. URL: http://economy.gov.ru/minec/about/structure/depOsobEcZone/2160930.

\section{Baikal Research Journal}


Особые экономические зоны в России переживают «вторую» волну своего развития. Тем не менее, при анализе их функционирования выявлен ряд проблем.

1. Несовершенство законодательства.

В настоящее время, наряду с Федеральным законом от 22.05.2005 г. № 116-ФЗ «Об особых экономических зонах Российской Федерации», действует еще ряд законов, определяющих порядок функционирования отдельных ОЭЗ (Калининградской и Магаданской областей, инновационного центра «Сколково»). То есть нет единого базового нормативного документа. Для решения этой проблемы возможно включить в закон об особых экономических зонах отдельные главы «Особая экономическая зона в Калининградской области», «Особая экономическая зона в Магаданской области» и «Инновационный центр «Сколково», на которые будут распространятся общие требования законодательства об ОЭЗ с учетом территориальных особенностей каждой из зон (погранично-пропускной и валютный режим в Калининградской области, налоговый режим в Магаданской области, территория и сроки существования зон и др.) [3, с. 5].

Кроме того, существуют «пробелы» в законодательстве в том, что касается условий создания ОЭЗ и определения прилегающих к ним территорий. Согласно земельному законодательству правовой режим использования земель в пределах особых экономических зон, а также на прилегающей к ним территории имеет ряд важных отличий от общего правила. Однако Земельный и Градостроительный кодексы РФ не раскрывают понятие «территория, прилегающая к ОЭЗ» [9, с. 37]. В соответствии с законом об ОЭЗ общая площадь прилегающей к промышленнопроизводственным ОЭЗ территории не должна превышать $40 \mathrm{kм}^{2}$, площадь прилегающей к технико-внедренческим ОЭЗ территории не должна превышать $4 \mathrm{\kappa m}^{2}$, а прилегающая к портовым ОЭЗ территория должна составлять не более $50 \mathrm{kм}^{2}$. Более детальное регулирование вопросов, связанных с территорией как самой ОЭЗ, так и прилегающей к ней, указанные федеральные законы не предусматривают. В целях определения прилегающей к ОЭЗ территории в Закон об особых экономических зонах необходимо внести изменения в части, касающейся способа установления прилегающей к ОЭЗ территории [9, с. 37].

Ответственность сторон при создании ОЭЗ законодательно не регламентируется. Ни закон об $0^{9}{ }^{9}$, ни договоры о создании ОЭЗ не содержат условий об ответственности сторон за выполнение своих обязанностей. Минэкономразвития РФ осуществляет делегирование отдельных полномочий по управлению ОЭЗ органу исполнительной власти субъекта РФ, на территории которого создана ОЭЗ, на основании соглашения ${ }^{10}$, либо управляющей компании (передача полномочий осуществляется на основании Приказа Минэкономразвития Р $\left.\Phi^{11}\right)$. В соглашениях также не закрепляется ответственность сторон, содержатся отсылки к положениям законодательства РФ, что не дает резидентам ОЭЗ гарантии защиты от нарушения прав или от невыполнения обязательств по соглашению, негативно влияет на развитие ОЭЗ [10, с. 280].

2. Отличие российских критериев отбора заявок на создание особых экономических зон от применяемых в мировой практике.

9 Об особых экономических зонах в Российской Федерации [Электронный ресурс] : федер. закон РФ от 22.07.2005 г. № 116-ФЗ : (ред. 03.07.2016) // СПС «Консультант-Плюс».

10 Об утверждении примерной формы соглашения о передаче полномочий по управлению особой экономической зоной органу исполнительной власти субъекта Российской Федерации [Электронный ресурс] : приказ Минэкономразвития РФ от 04.08.2016 № 502 // СПС «ГАРАНТ».

11 О порядке передачи отдельных полномочий по управлению особыми экономическими зонами управляющей компании [Электронный ресурс] : приказ Министерства экономического развития РФ от 06.04.2012 № 187 // СПС «ГАРАНТ».

\section{Baikal Research Journal}

электронный научный журнал Байкальского государственного университета 
Применяемые в настоящее время критерии отбора заявок на создание ОЭЗ в большей степени ориентированы на анализ социально-экономического положения региона и, как следствие, отдают приоритет развитым субъектам федерации. В то время как в мировой практике ОЭЗ создают полюса роста в депрессивных регионах. То есть при отборе заявок необходимо в большей степени ориентироваться на оценку имеющихся инвестиционных предложений [11, с. 2].

3. Система оценки эффективности ОЭЗ находится в стадии формирования.

4. Государство играет решающую роль в создании и управлении ОЭЗ.

Федеральный закон «Об особых экономических зонах Российской Федерации» 12 предусматривает создание в России ОЭЗ исключительно по решению Правительства РФ (статья 2). Это положение можно трактовать, как косвенный запрет на создание ОЭЗ решением региональных властей [12, с. 23].

Неоднократно выдвигались идеи по развитию российских ОЭЗ: привлечение частных инвесторов к созданию инфраструктурных объектов внутри самих зон; передача управления ОЭЗ регионам; активное использование механизма государственно-частного партнерства; сотрудничество бизнеса и региональных властей в создании региональных ОЭЗ.

Однако здесь же необходимо отметить следующую проблему - отсутствие опыта у администрации регионов. По мнению Жирковой С. Н., если региональная администрация не имеет адекватного представления о глобальном спросе и конкуренции, то она вряд ли способна создавать условия для привлечения в Россию высокотехнологичных компаний [12, с. 25].

Важным является вопрос инфраструктурной обеспеченности ОЭЗ. Первоначально предполагалось полное финансирование затрат на создание инфраструктуры за счет средств бюджета, в основном федерального. В современной же ситуации большое внимание уделяется привлечению частных инвестиций в инфраструктурный сегмент. Необходимо формировать новые схемы участия частного бизнеса в создании инфраструктурных объектов, которые позволили бы бизнесу извлекать адекватную прибыль. Один из возможных инструментов в данном случае - обеспечение долгосрочных кредитных ресурсов государственными гарантиями.

Кроме того, при создании ОЭЗ целесообразно использовать уже имеющиеся площади с инфраструктурным обеспечением. Это может привести как к экономии бюджетных средств на инфраструктуру, так и к облегчению для регионов задачи поиска подходящих земельных участков $[11$, с. $4-5]$.

5. Удаленность ОЭЗ от крупных городов.

ОЭЗ часто располагаются в отдалении от крупных городских агломераций, что делает их менее привлекательными для инвесторов и рабочей силы. ОЭЗ туристско-рекреационного типа располагаются в регионах, где имеются природные достопримечательности. Однако из-за удаленность таких регионов (например, оз. Байкал) для туристов более предпочтительны привычные места отдыха, такие, например, как побережье Черного и Азовского морей. В связи с чем необходимо комплексно подходить к развитию туризма, туристско-рекреационных и портовых типов ОЭЗ - наряду с созданием и развитием ОЭЗ активно заниматься дальнейшим благоустройством и развитием традиционных мест отдыха и туризма $[12$, c. 26$]$.

6. Отсутствие систематизированной информации о функционировании и результатах деятельности ОЭЗ.

Управляющая компания АО «Особые экономические зоны» публикует паспорта ОЭЗ и ежегодные отчеты о результатах функционирования российских

12 Об особых экономических зонах в Российской Федерации [Электронный ресурс] : федер. закон РФ от 22.07.2005 г. № 116-ФЗ : (ред. 03.07.2016) // СПС «Консультант-Плюс».

\section{Baikal Research Journal}

электронный научный журнал Байкальского государственного университета 
ОЭЗ. Однако в отчетах анализируются только отдельные показатели, нет анализа функционирования каждой ОЭЗ с момента ее создания. Паспорта ОЭЗ также не содержат достаточной информации о функционировании ОЭЗ, как и презентации зон, размещенные на их сайтах. В паспортах также отсутствует информация по доходам бюджета и налоговым доходам РФ.

Считаем необходимым создание единого информационного ресурса об особых экономических зонах для всех заинтересованных сторон, в котором была бы приведена систематизированная, исчерпывающая, достоверная и новейшая информация обо всех ОЭЗ. Также целесообразным было бы создание источника на данном ресурсе с древом всех нормативно-правовых документов, касающихся ОЭЗ, со всеми изменениями и дополнениями - это значительно бы облегчило поиск достоверной информации, дало возможность инвесторам и другим заинтересованным лицам, в том числе исследователям, быстро ознакомиться с последними нововведениями.

7. Недостаточно благоприятный инвестиционный климат России для привлечения иностранных инвестиций.

Приходу зарубежных компаний в Россию препятствуют следующие обстоятельства: 1) в ОЭЗ предоставляются только налоговые льготы, не применяются другие формы поддержки, тогда как за рубежом резиденты могут пользоваться консультативной помощью, централизованным маркетингом и PR, привлекать льготные кредиты [12, с. 25]; 2) руководство ОЭЗ не уделяет достаточного внимания маркетингу, особенно на внешних рынках (ранее уже отмечался недостаток систематизированной и полной информации об ОЭЗ в открытом доступе) [12, с. 25]; 3) в российских ОЭЗ применяются ограничения на виды деятельности; 4) политика государства в отношении ОЭЗ не является ясной и прозрачной (характерны постоянные задержки формальных процедур по открытию ОЭЗ и отсутствие стабильных «правил игры», например, форма Соглашения о передаче отдельных полномочий по управлению ОЭЗ была введена в 2015 г., а в 2016 г. уже отменена); 5) существуют технические сложности деятельности в ОЭЗ (длительный процесс получения статуса резидента ОЭЗ, жесткие требования к формам заявок и бизнес-планов, требования оценки социально-экономических эффектов не всегда понятны иностранным компаниям) [11, с. 6].

Решение указанных проблем путем совершенствования законодательства, отработки механизма планирования и оценки эффективности ОЭЗ, привлечения частных инвесторов для создания инфраструктуры ОЭЗ, улучшения инвестиционного климата будет способствовать более эффективному использованию ОЭЗ в России.

\section{Список использованной литературы}

1. Бутов В. И. Свободные экономические зоны. Методологические и организационные основы. Правовой и налоговый режим. Нормативная база / В. И. Бутов, В. Г. Игнатов. М. : Ось-89, 1997. - 192 с.

2. Павлов П. В. Особые экономические зоны как форма интеграции государства в систему международных экономических отношений / П. В. Павлов // Terra Economicus. 2008. - Т. 6, № 2-2. - С. 350-362.

3. Павлов П. В. Институциональные основы функционирования различных типов особых экономических зон / П. В. Павлов // Вестник таганрогского института управления и экономики. - 2011. - № 2. - С. 1-5.

4. Приходько С. В. Особые экономические зоны / С. В. Приходько, Н. П. Воловик. М. : ИЭПП, 2007. -268 с.

5. Данько Т. П. Свободные экономические зоны - катализатор развития рыночной экономики / Т. П. Данько, З. М. Окрут, А. А. Халдей. - Краснодар, 1991. - 44 с.

\section{Baikal Research Journal}

электронный научный журнал Байкальского государственного университета 
6. Федин П. А. Свободные экономические зоны в России: мнения и точки зрения на определение понятия / П. А. Федин // Фундаментальные и прикладные исследования кооперативного сектора экономики. - 2012. - № 2. - С. 41-47.

7. Шмонов Н. Н. Историческое исследование проблем развития особых экономических зон / Н. Н. Шмонов. - Казань : Изд-во КГУКИ, 2010. - 158 с.

8. Коробова О. В. Анализ теоретических подходов к понятию «свободная экономическая зона» / О. В. Коробова, Н. В. Наумова // Ученые записи Тамбовского отделения РоСМУ. 2015. - № 3. - С. 1-4.

9. Кучинская А. В. Условия создания особых экономических зон и определения прилегающей к особым экономическим зонам территории в Российской Федерации / А. В. Кучинская, С. А. Липски // Имущественные отношения в Российской Федерации. 2014. - № 3. - С. 34-38.

10. Волокитина Ю. В. Повышение инвестиционной привлекательности ОЭЗ путем совершенствования правового взаимодействия субъектов ОЭЗ / Ю. В. Волокитина // Пробелы в российском законодательстве. - 2011. - № 5. - С. 279-281.

11. Илющенко Н. А. Проблемы и перспективы особых экономических зон как формы государственно-частного партнерства / Н. А. Илющенко // Вестник Адыгейского государственного университета. Серия 5, Экономика. - 2011. - № 2. - С. 1-7.

12. Жиркова С. В. Развитие особых экономических зон в России как инструмент повышения инновационного потенциала: недостатки, преимущества и перспективы / С. В. ЗЖиркова // Социально-экономические явления и процессы. - 2012. — № 7-8. C. 22-28.

\section{References}

1. Butov V. I., Ignatov V. G. Svobodnye ekonomicheskie zony. Metodologicheskie $i$ organizatsionnye osnovy. Pravovoi $i$ nalogovyi rezhim. Normativnaya baza [Free Economic Zones. Free economic zones. Methodological and organizational basics. Legal and tax regime]. Moscow, Os'-89 Publ., 1997. 192 p.

2. Pavlov P. V. Special economic zones as a form of state integration into the system of International Economic Relations. Terra Economicus, 2008, vol. 6, no. 2-2, pp. 350-362. (In Russian).

3. Pavlov P. V. Institutional basics of functioning of various types of the Special Economic Zones. Vestnik taganrogskogo instituta upravleniya $i$ ekonomiki = Bulletin of Taganrog Institute of Management and Law, 2011, no. 2, pp. 1-5. (In Russian).

4. Prikhod'ko S. V., Volovik N. P. Osobye ekonomicheskie zony [Special Economic Zones]. Moscow, Institute of Economy of Transition Period. Publ., 2007. 268 p.

5. Dan'ko T. P., Okrut Z. M., Khaldei A. A. Svobodnye ekonomicheskie zony - katalizator razvitiya rynochnoi ekonomiki [Free Economic Zones - a catalyst for market economy development]. Krasnodar, 1991. 44 p.

6. Fedin P. A. Free Economic Zones in Russia: opinions and points of view on the concept definition. Fundamental'nye i prikladnye issledovaniya kooperativnogo sektora ekonomiki = Fundamental and Applied Research of Cooperative Economic Sector, 2012, no. 2, pp. 41-47. (In Russian).

7. Shmonov N. N. Istoricheskoe issledovanie problem razvitiya osobykh ekonomicheskikh zon [Historical research of development problems for Special Economic Zones]. Kazan state University of culture and arts Publ., 2010, $158 \mathrm{p}$.

8. Korobova O. V., Naumova N. V. Analysis of theoretical approaches to the concept of «free economic zone». Uchenye zapiski Tambovskogo otdeleniya RoSMU = Memoirs of Tambov Branch of RUYA, 2015, no. 3, pp. 1-4. (In Russian).

9. Kuchinskaya A. V., Lipski S. A. Terms of Special Economic Zones creation and determination of the territory adjacent to Special Economic Zones in the Russian Federation. Imushchestvennye otnosheniya $v$ Rossiiskoi Federatsii = Property Relations in the Russian Federation, 2014, no. 3, pp. 34-38. (In Russian).

10. Volokitina $\mathrm{Yu}$. V. The investment attractiveness increase of the SEZ by improving the legal interaction of the SEZ subjects. Probely $v$ rossiiskom zakonodatel'stve $=$ Gaps in Russian Legislation, 2011, no. 5, pp. 279-281. (In Russian).

\section{Baikal Research Journal}


11. Ilyushchenko N. A. Problems and prospects of Special Economic Zones as a form of public-private partnership. Vestnik Adygeiskogo gosudarstvennogo universiteta. Seriya 5, Ekonomika = Bulletin of Adygeya State University, Series 5, Economics, 2011, no. 2, pp. 1-7. (In Russian).

12. Zhirkova S. V. Development of Special Economic Zones in Russia as an instrument of increasing the innovation potential: shortcomings, advantages and prospects. Sotsial'no-ekonomicheskie yavleniya i protsessy = Socio-Economic Phenomena and Processes, 2012, no. 7-8, pp. 22-28. (In Russian).

\section{Информация об авторах}

Чепинога Оксана Александровна - кандидат экономических наук, доцент, кафедра мировой экономики и международного бизнеса, Байкальский государственный университет, 664003, г. Иркутск, ул. Ленина, 11, e-mail: ChepinogaOA@bgu.ru.

Солодков Михаил Викторович - кандидат экономических наук, доцент, кафедра мировой экономики и международного бизнеса, Байкальский государственный университет, 664003, г. Иркутск, ул. Ленина, 11, e-mail: detrester@yandex.ru.

Селенова Анастасия Эдуардовна - студент, кафедра мировой экономики и международного бизнеса, Байкальский государственный университет, 664003, г. Иркутск, ул. Ленина, 11, e-mail: jinast.semenova@yandex.ru.

\section{Authors}

Oksana A. Chepinoga - PhD in Economics, Associate Professor, Chair of World Economics and International Business, Baikal State University, 11 Lenin St., 664003, Irkutsk; e-mail: ChepinogaOA@bgu.ru.

Mikhail V. Solodkov - PhD in Economics, Associate Professor, Chair of World Economics and International Business, Baikal State University, 11 Lenin St., 664003, Irkutsk; e-mail: detrester@yandex.ru.

Anastasiya E. Semenova - Student, Chair of World Economics and International Business, Baikal State University, 11 Lenin St., 664003, Irkutsk; e-mail: jinast.semenova@yandex.ru.

\section{Для цитирования}

Чепинога О. А. Проблемы функционирования и перспективы развития особых экономических зон в России / О. А. Чепинога, М. В. Солодков, А. Э. Семенова // Baikal Research Journal. - 2017. — T. 8. — № 3. — DOI : 10.17150/2411-6262.2017.8(3).4.

\section{For citation}

Chepinoga O. A., Solodkov M. V., Semenova A. E. Problems of functioning and development prospects for special economic zones in Russia. Baikal Research Journal, 2017, vol. 8, no. 3. DOI: 10.17150/2411-6262.2017.8(3).4. (In Russian).

\section{Baikal Research Journal}

